\title{
Spesific Array-CGH Design and Application in Skeletal Dysplasia
} İskelet Displazilerine Özgü Array-CGH Dizaynı ve Uygulaması

\author{
Aydın H, Kalaycı Yiğin A, Özdemir F, Seven M \\ İstanbul Üniversitesi-Cerrahpaşa, Cerrahpaşa Tıp Fakültesi, Tibbi Genetik Anabilim Dalı, İstanbul, Türkiye
}

\begin{abstract}
Skeletal dysplasia (SD) and associated disorders classified 42 groups and 436 defined diseases. Totally 364 genes are associated with $S D$. The design of high-resolution array-CGH allows research to be done with advanced technology in the genetic diseases that still unknown etiology and molecular basis.

The aim of this study was to design a new high-resolution arrayCGH microchip for skeletal dysplasias.

To work; Eight patients who were admitted to Cerrahpaşa Medical Faculty, Medical Genetics Department, and diagnosed as skeletal dysplasia but had no known chromosomal abnormalities, any change that can be detected by routine molecular techniques or no metabolic cause were included.

We designed a microarray slight containing 14127 probes for the intronic and exonic regions of the 226 SD genes and also the 44K Array-CGH probe group that is standardized by ISCA. Data obtained from these designed array-CGH slides were evaluated with the CytoGenomics program. The investigation by this method achieved 85\% success in patients. We detected copy number changes in 7 out of 8 patients. The detected changes have the possibility of being candidate genes for related syndromes. We think that the designed microarray slight will be useful for re-identifying the criteria of SD and new subgroups and also describing the candidate genes of SD with unknown etiology. ÖZET

İskelet displazileri 42 ana gruba ayrllan 436 hastallktan oluşmaktadır. Bu hastallklar yaklaşılk 364 genin bir veya birkaçı ile ilişkilendirilmektedir. Yüksek rezolüsyonlu array-CGH dizaynı, etiyolojisi ve moleküler temelleri iyi bilinmeyen genetik hastalıklarda, ileri teknolojik araștırmaların yapılmasina olanak sağlamaktadır.

Bu çalışma için iskelet displazilerine özgü yüksek rezolüsyonlu yeni bir arrayCGH mikroçip tasarlanması amaçlandl.

Çalışmaya; Cerrahpaşa Tip Fakültesi, Tıbbi Genetik Anabilim Dalı'na başvuran ve iskelet displazisi tanısı alan, ancak etiyolojisinde bilinen herhangi bir kromozomal anomali, rutin moleküler tekniklerle tespit edilebilen bir değişim veya metabolik bir neden bulunamayan 8 hasta dahil edildi.

Tüm genom incelemesi için ISCA tarafindan tasarlanan $44 K$ array-CGH prob grubuna ilave olarak iskelet displazilerinde tanımlanan 226 gen bölgesine özgü, ekzonik ve intronik alanları da kapsayacak șekilde 14127 adet prob kullanarak yeni bir mikroçip dizayn edildi. Tasarlanan bu array-CGH slaytlarından elde edilen veriler CytoGenomics programiyla değerlendirildi. Hazırlanan mikroçiplerle incelenen hastalarda $\% 85$ oranında başarı sağlandı. Analiz edilen 8 hastanın 7 'sinde anlamlı kopya sayısı değişikliği saptandl. Belirlenen bu değissikliklerin ilișkili sendromlar için aday genler olabileceği, bu tasarımın modifive șekilleriyle iskelet displazisi tanı kriterlerinin yeniden belirlenebileceği, yeni alt tiplendirmelere yol gösterebileceği ve etiyolojisi bilinmeyen displazilerin moleküler temellerinin açıklanmasına imkan sağlayabileceği düşünülmektedir.
\end{abstract}

Key Words:

Skeletal Dysplasia,

Array-CGH,

Design of Microarray.

Anahtar Kelimeler:

Iskelet Displazisi,

Array-CGH,

Mikroarray Dizaynt.

\section{Gíriș}

İskelet displazisi (ID); kemik ve kıkırdağın şekil, boyut ve yoğunluk değişimini içeren; genetik nedenlerle ekstremite, göğ̈̈s, kafatası ve vertebra gibi iskeleti oluşturan yapıların anormal gelişimiyle karakterize heterojen bir hastalık grubudur (1). 3000 ila 6000'de 1 görüldüğü tahmin edilmekte ve perinatal ölümlerin $\% 0,9$ 'unun ID'lerinden kaynaklandığ bildirilmektedir $(2,3)$.

İD, Uluslararası İskelet displazisi Derneği (ISDS) tarafından klinik, moleküler, biyokimyasal ve/veya radyolojik kriterlere göre 436 hastalıktan oluşan 42 gruba ayrılmıştır. Bunlarla ilişkili bir veya birden fazla genin içinde yer aldığı toplam 364 farklı gen tanımlanmıştır. Moleküler çalışmalarla belirlenen değişimler genellikle patojenik, olası patojenik, klinik önemi bilinmeyen ya da hastalığa neden olduğu bilinmeyen varyantlar olarak sinıflandırılmaktadır (4).

İnsan genom projesinin sağladığı gelişmeler sayesinde iskelet displazileri daha kolay anlaşılır hale gelmiștir. Gelişen teknoloji ile iskelet gelişimi, büyümesi ve devamını sağlayan çok sayıda genler ve yolaklar tanımlanmıştır. Genler ile klinik ve biyokimyasal sonuçlar arasında nasıl bir ilişki olduğunu tanımlayabilen temel moleküler mekanizmalar giderek daha fazla anlaşılmaktadır (5).

Received: 17.10 .2019

Accepted: 24.10 .2019

Correspondence: Prof. Dr. Mehmet Seven, İstanbul Üniversitesi-Cerrahpaşa, Cerrahpaşa Tıp Fakültesi, Tıbbi Genetik Anabilim Dalı, İstanbul, Türkiye. Email: mimseven@istanbul.edu.tr Phone: +90 212 4143000-21304 Pbx: +90 2124143184

Cite this article as: Aydın H, Kalaycı Yiğin A, Özdemir F, Seven M. Spesific Array-CGH Design and Application in Skeletal Dysplasia. Phnx Med J. 2019;1(1):26-30. 
Array Karşılaştırmalı Genomik Hibridizasyon (CGH), submikroskobik DNA kopya sayısı değişikliklerini haritalama ve tespit olanağ 1 sağlayan yüksek çözünürlükte gelişmiş bir teknolojidir. Array-CGH düzenli bir sıra ve boyutta yerleştirilen problarla genomdaki çok küçük değişimlerin tespitine imkan sağlamaktadır. Array-CGH, tasarım ve üretime bağlı olarak farklılık gösterirken, tüm genom analizlerine olanak sağlayabilen bir yöntemdir. Aday gen araştırmalarına da tartışılmaz katkılar sağlamaktadır. Array-CGH moleküler etiyolojisi bilinmeyen bozukluklarda tüm genom incelemelerinde ilk basamak olarak kullanılabilir bir yöntemdir. Ayrıca moleküler etiyolojisi bilinen hastalıklarda, ilgili genin nükleotid dizisi incelenmesine rağmen, herhangi bir değişiklik tespit edilemediği durumlarda da ilk basamak olarak kullanılabilir $(6,7)$.

Bu çalışmada; ID ile ilgili olduğu düşünülen genomik bölgeleri yüksek rezolüsyonlu tek bir slaytta toplayarak hastalığın etiyolojisinin belirlenmesine yönelik çalışmalara imkan sağlanması, embriyolojik olarak kemik ve kıkırdak gelişiminde etkili olan genomik bölgelerin belirlenmesine katkıda bulunulması, heterojen ve dört yüzden fazla alt tipi belirlenmiş olan ID'li hastalarda olası mikrodelesyon veya duplikasyon gibi yeniden düzenlenmelerin klinik bulgularla ilişkilendirilmesi ve ID'lerin alt tipleriyle ilişkili submikroskobik değişikliklerin tespiti durumunda bu hastalıkla ilişkili yeni genlerin belirlenmesi amaçlanmıştır.

\section{MATERYAL METOD}

Çalışma grubu, Cerrahpaşa Tıp Fakültesi Tıbbi Genetik Anabilim Dalı Genetik Polikliniğinde ID tanısı konularak izlenen hastalar arasından seçilerek oluşturuldu. Hasta grubuna etiyolojisinde bilinen herhangi bir moleküler değişim bulunmayan vakalar dahil edildi. Çalışmaya alınacak hastalar, detaylı öykü, fizik muayene, radyolojik görüntülemeler, biyokimyasal ve metabolik testler ile moleküler analizler yapıldıktan sonra belirlendi. Bu hastalar arasından iskelet anomalisi olmayan veya bilinen genin incelenmesi tamamlanmayanlar ve ID içermeyip multipl konjenital anomalisi olanlar çalışma dişında birakild1.

Tüm ID'li hastalara karyotip analizi yapıldı. Herhangi bir kromozomal anomali saptanan hastalar ve doğumsal metabolik bozukluklara bağlı oluşan İ'li vakalar çalışmaya dahil edilmedi. Bu amaçla hastalara idrarda organik asit ve kanda amino asit analizi ile metabolik testler yapıldı. Değerlendirmeler sonucunda 6's1 erkek, 2'si kız olmak üzere toplam 8 hasta çalışıldı.

Tüm hasta ve ailelerinden bilgilendirilmiş onam alındı. Hastalardan örnek alım ve analiz çalışmalarına etik kurul onayı alındıktan sonra başlandı.

\section{İskelet Displazilerine Özgü Yüksek Rezolüsyonlu Array-CGH Tasarımı}

ISDS tarafindan İD ile ilişkilendirilmiş 226 gen bölgesiyle birlikte Uluslararası Sitogenetik Array Standardizasyon Grubu (ISCA) tarafindan belirlenen kromozomal bölgelerin de incelenmesini sağlayabilecek şekilde tüm genomu tarayan, lokusa özgü tasarım olanağı sunan gelişmiş teknolojiler kullanarak Array-CGH slayt tasarımı yapıldı. Yüksek özgüllükte eşleşmeye olanak sağlayan 60 mer problar içeren, isteğe bağlı tasarım yapılmasına olanak sunan Agillent Inc. tarafindan üretilen "SurePrint G3 Custom CGH, 8x60K" slaytı ile çalışma yapıldı. Prob dizaynı için earray.chem.agilent.com/earray mikroarray programı kullanıldı. Programın kullanımımıza sunduğu problar, ilgili lokusları kapsayan 200-500 bç aralığında olacak şekilde, yüksek rezolüsyonlu bir mikroçip üzerine yerleştirildi. Böylece hassas (zoom-in) incelemeye olanak sunan bir slayt hazırlanmış oldu. Analizde sinyal kirliliği oluşmaması ve değerlendirmenin güvenli aralıkta yapılabilmesi için prob yerleşimi, sinyal log2 değeri -1 ve +1 aralığında olacak şekilde tasarlandı. İD için belirlenen 226 gen bölgesini incelemek amacıyla ilgili genlerin ekzonik ve intronik alanlarını kapsayan 14127 prob kullanıldı. ISCA'nın tanımladığ 44000 adet prob, incelediğimiz lokuslar dışında olabilecek kopya sayısı değişimlerini (CNV) yakalayabilmek amaciyla tüm genomu kapsayacak şekilde mikroçipe ilave edildi. Tarama cihazından elde edilen prob sinyallerini sağlıklı okuyabilmesi için sistem içinden bir normalizasyon ve 5 tekrarlık bir replikasyon grubu belirlenip tasarıma dahil edildi.

UCSC genome browser aracılığıyla, tasarladığımız probların hem ilgili lokuslar hem de tüm genom üzerindeki dağılımı incelendi ve prob tasarımı konfirme edildi.

Sonuç olarak, tüm genomu taramaya uygun olan 44000 proba, ID ile ilgili 226 gene özgü 14127 prob eklenerek mikroçip tasarımı tamamlandı.

\section{DNA izolasyonu}

DNA eldesi ticari DNA izolasyon kiti (Roche Diagnostics GmbH, Mannheim, Germany) ile gerçekleştirildi. Çalışma saflık değeri 1.7 - 1.85 arasında olan DNA örnekleriyle yapıldı.

\section{Array-CGH Uygulama Protokolu}

Çalışma SurePrintG3 Human CGH Microarray Kit, 8x60K (Agilent Inc.) protokolundeki enzimatik yönteme göre yapıldı. Enzimatik yöntemde DNA'da 200-500 bç'lik fragmanlar oluşturularak daha kolay hibridizasyon sağlanmaktadır. Çalışma protokolüne uygun şekilde sırayla enzim kesimi, işaretleme, işaretlemenin saflaştırılması, hibridizasyon ve hibridizasyon sonrası yıkama yapıldı. 
Tablo 1: Hastaların klinik, radyolojik ve laboratuvar bulguları

\begin{tabular}{|c|c|c|c|c|}
\hline Olgu & Fizik Muayene Bulguları & Radyolojik Bulgular & Karyotip & Metabolik testler \\
\hline 1 & $\begin{array}{l}\text { Ekstremitelerde multipl şişlik, } \\
\text { deformasyon, hemanjiomlar }\end{array}$ & Multipl enkondrom ve punktat lezyonlar, & 46, XY & $\mathrm{N}$ \\
\hline 2 & $\begin{array}{l}\text { Frontal çöküklük, brakisefali, } \\
\text { dismorfik yüz }\end{array}$ & Sintelensefali, wormian kemik veya split metopik sütür & 46, XY & $\mathrm{N}$ \\
\hline 3 & Ağır kifoskolyoz & Hemivertebra, rotoskolyoz, & 46, XX & $\mathrm{N}$ \\
\hline 4 & $\begin{array}{l}\text { Dismorfik yüz, kisa boy, pektus } \\
\text { karinatum }\end{array}$ & $\begin{array}{l}\text { Horizontal asetabulum, metafizyel düzensizlik, skolyoz, } \\
\text { vertebralarda yarıklanma, ileri kemik yaşı }\end{array}$ & 46, XY & $\mathrm{N}$ \\
\hline 5 & Dismorfik yüz, kısa boyun & $\begin{array}{l}\text { Horizontal asetabulum, pelviste "İsveç anahtarı" femur başı, } \\
\text { coxa vara, ileri kemik yaşı, }\end{array}$ & 46, XX & $\mathrm{N}$ \\
\hline 6 & $\begin{array}{l}\text { Makrosefali, kisa boy, mezomelik } \\
\text { k1salık }\end{array}$ & $\begin{array}{l}\text { Spondiler ve metafizer düzensizlik, mezomelik kısalık, } \\
\text { gecikmiş kemik yaşı }\end{array}$ & 46, XY & $\mathrm{N}$ \\
\hline 7 & $\begin{array}{l}\text { Dismorfik yüz, aglossi, bifid uvula, } \\
\text { adaktili, hafif MR }\end{array}$ & Metatarsal terminal ameli, adaktili & 46, XY & $\mathrm{N}$ \\
\hline 8 & Dismorfik yüz, korneal opasite & $\begin{array}{l}\text { Platispondili, metafizyal düzensizlik, diafizyal şekil } \\
\text { bozukluğu, femur başında düzleşme, asetabular çatıda } \\
\text { silinme ve pelvis restriksiyonu, serebellar vermis hipoplazisi, } \\
\text { serebellar molar diş işareti }\end{array}$ & 46, XY & $\mathrm{N}$ \\
\hline
\end{tabular}

\section{Slaytların Taranması ve Sonuçların Değerlendirilmesi}

Slayt, yıkama sonrası tarama için, Agilent Nukleik Asit Tarayıcı'ya yerleştirildi. Okuma profili Agilent G3_CGH 8x60K'a için ayarland. Analiz için elde edilen veriler Agilent CytoGenomics 1.5 programına Design dosyaları ile beraber yüklendi. Yapılan analizde amplifikasyon için temel olarak 0.4, delesyon için 0.6 'nın üstü anlamlı kabul edildi.

\section{BULGULAR}

\section{Hastaların Bulguları}

Çalışmaya, Cerrahpaşa Tıp Fakültesi Tıbbi Genetik Anabilim Dalı Genetik Polikliniğinde takip edilen 2'si k1z, 6'sı erkek olmak üzere, iskelet displazili toplam 8 hasta alındı. Kızların yaş ortalaması $16^{6 / 12}$ yaş, erkek hastaların yaş ortalaması 11 yaş, tüm hastaların yaş ortalaması ise $12^{4 / 12}$ yaş olarak hesapland. Hastaların en küçüğü $1^{6 / 12}$ yaşında, en büyüğü ise 39 yaşındaydı. Her bir hastanın klinik ve laboratuvar bulgusunun bağımsız ve farklı olması nedeniyle olgular tek tek ele alınarak değerlendirildi (Tablo 1) ve örnek olarak olgu 1, 3 ve 4'e ait radyolojik bulgular Şekil 1'de sunuldu.

\section{Array-CGH Bulguları}

Çalışmada array-CGH protokolü uygulamasının ilk aşaması olan enzimatik kesim sonrası hasta ve referans DNA'larının jel görüntüleri kaydedildi.

Protokolün işaretleme aşamasından sonra DNA ve boya konsantrasyonları ölçümleri kullanılarak işaretleme değeri, spesifik aktivite ve ürün (yield) değerleri hesaplandı. Hesaplanan değerlerin hibridizasyon için uygun olduğuna karar verilerek çalışmaya devam edildi.

Array-CGH laboratuvar işlemleri bittikten sonra tüm olguların bir arada olduğu slayt görüntüsü ve her bir olgu için ayrı QC raporu elde edildi.
Veriler Cytogenomics 1.5 versiyonu ile analiz edildi. Maffucci sendromu tanılı 1'nolu olgunun 14q13.1 bölgesinde 302013 bç uzunluğunda 0.6 değerinde amplifikasyon, ID tanılı 3 nolu olgunun sirasiyla $3 q 28$ ve 11q11 bölgesinde 3755 ve 82635 bç uzunluğunda 0.9 ve -3.4 değerinde delesyon, ID tanılı 4 nolu olgunun sirayla $8 \mathrm{p} 11.22,8 \mathrm{q} 24.3,18 \mathrm{q} 22.3$ ve Xq21.1 bölgesinde 127265, 137335, 464417 ve 268412 bç uzunluğunda $1.15,1.01,0.78$ ve 0.79 değerinde

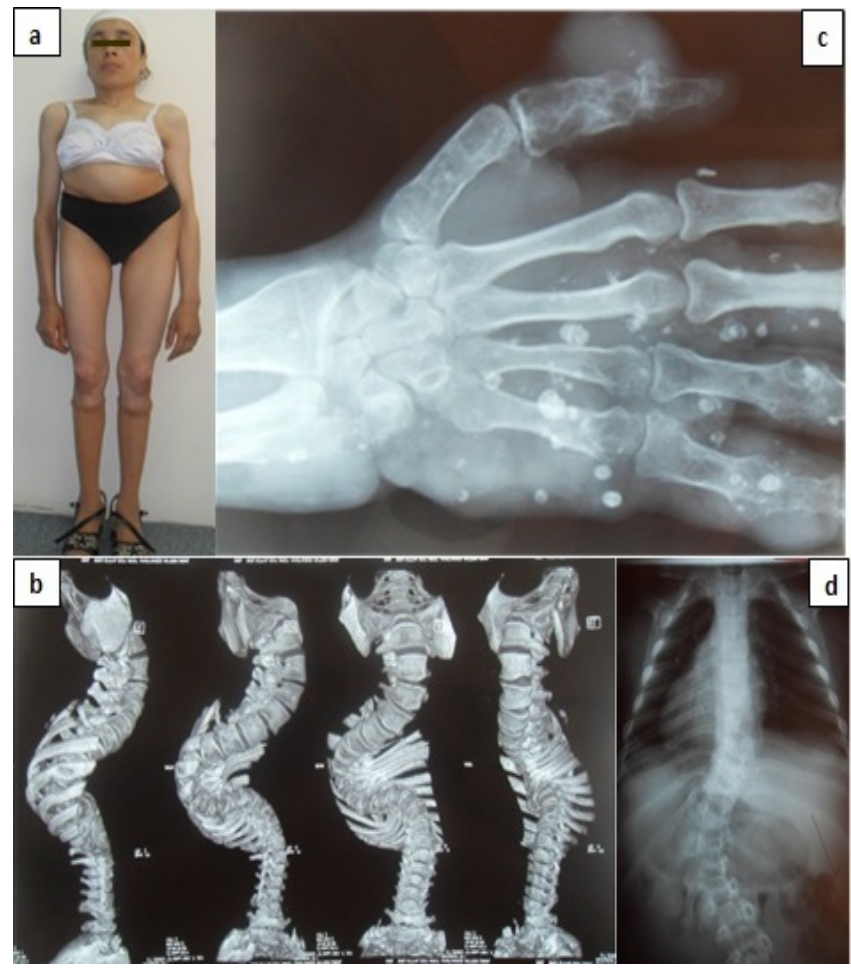

Şekil 1: a-b) 3 no'lu olgunun fizik ve vertebral BT'de skolyoz görünümü, c) 1 no'lu olgunun sağ el grafisinde enkondrom ve punktatlar d) 4 no'lu olgunun torako-vertebral grafisinde skolyoz görünümü. 
Tablo 2: Olgularda submikroskobik değişiklik gösteren bölgeler ve özellikleri

\begin{tabular}{clllcl}
\hline Olgu & Lokalizasyon & Değişim Boyutu & Band & Prob & Del/Dup \\
\hline 1 & chr14: 34618387-34920399 & 302013 & $\mathrm{q} 13.1$ & 5 & 0.604464 \\
\hline 3 & chr11:55368154-55450788 & 82,635 & $\mathrm{q} 11$ & 3 & $-3,433067$ \\
\hline 3 & chr3:189364173-189367927 & 3,755 & $\mathrm{q} 28$ & 4 & $-0,930716$ \\
\hline 4 & chr8:39258894-39386158 & 127,265 & $\mathrm{p} 11.22$ & 3 & 1,157281 \\
\hline 4 & chr8:145811171-145948505 & 137,335 & $\mathrm{q} 24.3$ & 3 & 1,013028 \\
\hline 4 & chr18:68784844-69249260 & 464,417 & $\mathrm{q} 22.3$ & 7 & 0,785639 \\
\hline 4 & chrX:77395711-77664122 & 268,412 & $\mathrm{q} 21.1$ & 5 & 0,791744 \\
\hline 5 & chr7:125343961-125669552 & 325,592 & $\mathrm{q} 31.33$ & 5 & $-0,953419$ \\
\hline 5 & chr7:143852973-144204173 & 351,201 & $\mathrm{q} 35$ & 5 & 0,826954 \\
\hline 6 & chr8:39258894-39386158 & 127,265 & $\mathrm{p} 11.22$ & 3 & $-5,718045$ \\
\hline 6 & chr10:46984913-47590995 & 606,083 & $\mathrm{q} 11.22$ & 5 & 0,837165 \\
\hline 6 & chr15:20686196-22173977 & $1,487,782$ & $\mathrm{q} 11.1-\mathrm{q} 11.2$ & 3 & 1,118392 \\
\hline 7 & chr3:189364173-189367927 & 3,755 & $\mathrm{q} 28$ & 4 & $-1,155009$ \\
\hline 8 & chr1:247962269-248563836 & 601,568 & $\mathrm{q} 44$ & 11 & 0,752796 \\
\hline 8 & chr2:242930600-243007359 & 76,760 & $\mathrm{q} 37.3$ & 4 & $-0,974070$ \\
\hline 8 & chr10:46984913-47590995 & 606,083 & $\mathrm{q} 11.22$ & 5 & 0,903783 \\
\hline$*$ del: delesyon (kayıp); dup: duplikasyon, (artıs) & & & \\
2 no'lu olguda herhangi bir değişim tespit edilmediği için tabloda yer verilmemiştir. & \\
\hline & & & & &
\end{tabular}

amplifikasyon, Desbuquois sendromu tan1lı 5'nolu olgunun 7q31.33 bölgesinde 325592 bç uzunluğunda 0.95 değerinde delesyon ve 7q35 bölgesinde 351201 bç uzunluğunda 0.82 değerinde amplifikasyon, IDD tanılı 6 nolu olgunun 8p11.22 bölgesinde 127265 bç uzunluğunda -5.71 değerinde delesyon ve 10q11.22, 15q11.1-q11.2 bölgesinde 606083 ve 1487782 bç uzunluğunda 0.83 ve 1.11 değerinde amplifikasyon, Aglossi-adaktili Sendromu tanılı 7 nolu olgunun 3q28bölgesinde 3755 bç uzunluğunda -1.15 değerinde delesyon (Şekil 2), Joubert sendromu + ID tanılı 8 nolu olgunun sirayla 1q44 ve 10q11.22 bölgesinde 601568 ve 606083 bç uzunluğunda 0.75 ve 0.90 değerinde amplifikasyon, ayrıca 2q37.3 bölgesinde 76760 bç uzunluğunda -0.97 değerinde delesyon olduğu saptand1. 2 nolu olguda ise herhangi bir değişim tespit edilmedi. Analiz verileri Tablo 2'de gösterilmiştir.

\section{TARTIŞMA}

İD için ISDS tarafindan sınıflama yapılmasına rağmen tanı kriterlerinin belirlenmesi oldukça zordur. İD'nde klinik ve radyolojik bulguların birbirine benzemesi nedeniyle en sağlıklı bilgi moleküler tanı yöntemleriyle elde edilmektedir. İD'lerin çoğunda ilişkili genler tanımlanmış, ilişkisi bilinmeyen genlerle ilgili moleküler çalışmalara devam edilmektedir (4). Etiyolojisi bilinmeyen bu tip İD'leri için günümüzde tüm ekzom sekanslama (WES), klinik ekzom (CES) ve İD'lerine özgü gen panelleri yeni nesil dizileme (NGS) gibi gelişmiş yöntemlerle tanı konulmaya çalışılmaktadır (8).

Akondroplazi, Apert Sendromu gibi İD vakalarında tek nükleotid değişimleri rol oynarken, epifiziyal displazi olgularında mikrodelesyon ve mikroduplikasyon gibi mutasyonlar hastalığa neden olabilmektedir $(9,10)$. Kopya sayısı varyasyonları (CNV) DNA'nın bazı bölgelerinin kopya sayısındaki polimorfik farklılıklardır. Bu değişiklikler, 1 kilobazdan 10'larca megabaza uzayabilen DNA bölgeleri olup, tüm genoma dağılmış halde bulunurlar. Patolojik kopya sayısı değişiklikleri ise delesyon veya duplikasyon şeklinde olabilmektedir. Yapısal varyasyonlar genelde birçok geni ve bu genlerin anlatımını düzenleyen bölgeleri etkileyebilir. Ayrıca genomun bazı bölgelerinde

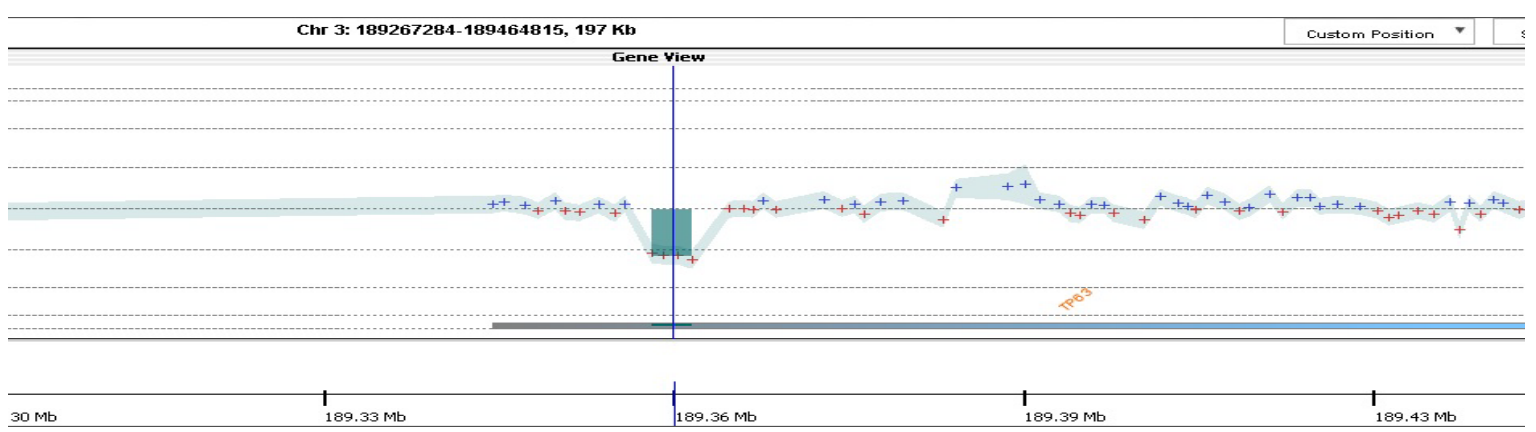

Şekil 2: 7 no’lu olguda tespit edilen delesyon görüntüsü. 
belirgin bir fenotipe yol açmadıkları gibi bazen de gen dozajını ve anlatımını olumsuz etkileyebilirler. Bu etkileşim sonucunda, tek başlarına ya da başka genetik ve çevresel faktörlerle birlikte hastalık nedeni olabilmektedirler $(6,7,11)$.

El-Gharbawy AH ve arkadaşları tarafindan yapılan çalışmada kleidokranial dizostozis ve hipofosfatazyalı bir olguda $R U N X 2$ geninin nükleotid dizi analizinde herhangi bir değişim bulunamamış, yüksek rezolüsyonlu array-CGH analizinde ise RUNX2 geninin C-terminal kısmında mikrodelesyon olduğu tespit edilmiştir (12). Bu çalışma etiyolojisi bilinmeyen olgularda öncelikli olarak mikrodelesyon/mikroduplikasyon araştırılması gerektiğine ve tasarladığımız slaytın önemine işaret etmektedir.

Tasarlanan bu yeni mikroçip ile analiz edilen 8 hastanın 7'sinde patojenik, klinik önemi bilinmeyen ya da hastalığa neden olduğu düşünülmeyen varyantlar tespit edildi. Bir hastada ise herhangi bir değişiklik tespit edilmedi. Elde ettiğimiz veriler 1şığında, tüm genom ve lokusa özgü prob grubları içermesi nedeniyle yeni tasarladığımız array-CGH mikroçip, moleküler etiyolojisi saptanmamış iskelet displazilerinde ilk basamak tarama yöntemi olarak kullanıma uygun hale getirildi. $\mathrm{Bu}$ çalışmada, elde edilen verilerle tasarladığımız bu yeni mikroçipin güvenli bir şekilde kullanılabileceği gösterildi.

Elde edilen sonuçlara göre literatürde "zoom-in” ya da "high resolution” array-CGH olarak da geçen bu lokusa özgü mikroçip tasarımının yeni nesil dizileme tekniklerinden önce maliyeti düşürmesi nedeniyle ön tarama yöntemi olarak hem araştırma hem de rutin amaçla kullanılabileceği düşünülmektedir.

\section{Çıkar çatıșması}

Tüm yazarlar çıkar çatışması olmadığını beyan eder.

\section{Teşekkür}

Bu çalışma İstanbul Üniversitesi Bilimsel Araştırma Projeleri Birimi tarafından desteklenmiştir. Proje numarası:

\section{KAYNAKLAR}

1. Urist M.R., Fundamental and Clinical Bone Physiology, Philadephia: J.B. Lippincott, 1980.

2. Rasmussen S.A., Bieber F.R., et al., Epidemiology of osteochondrodysplasias: changing trends due to advances in prenatal diagnosis. Am J Med Genet. 1996; 61: 49-58.

3. Doray B., Favre R., et al. Prenatal sonographic diagnosis of skeletal dysplasia: A report of 47 cases. Ann Genet. 2000 ; 43 : 163-169.

4. K. A. Geister and S. A. Camper, “Advances in skeletal dysplasia genetics,” Annual Review of Genomics and Human Genetics 2015; vol. 16, pp. 199-227.

5. Savarirayan R., Best Practice \& Research Clinical Endocrinology and Metabolism, 2002; 16 (3): 547-560,

6. Lupski J.R., Stankiewicz P., Genomic Disorders, The Genomic Basis of Disease. Humana Press, 2006; Part 27: $389-400$.

7. Jao-Shwann L., Shimojima K., Yamamoto T., Application of Array-based Comparative Genome Hybridization in Children with Developmental Delay or Mental Retardation. Pediatr Neonatol., 2008; 49 (6): 213-217.

8. Sung Yoon Cho, Dong-Kyu Jin. Guidelines for genetic skeletal dysplasia for pediatricians. Ann Pediatr Endocrinol Metab 2015;20:187-191.

9. Francomano C.A., Achondroplasia. In: Pagon RA, Bird TD, Dolan CR, Stephens K, editors. GeneReviews [Internet]. Seattle (WA): University of Washington, Seattle; 1993-1998 Oct 12 [updated 2006 Jan 09].

10. Kannu P., Oei P., Slater H.R., Khammy O., Aftimos S., Epiphyseal dysplasia and other skeletal anomalies in a patient with the 6p25 microdeletion syndrome. Am J Med Genet Part A 2006; 140A: 1955-1959.

11. Stevenson R.E., Hall J.G., Skeletal Dysplasia. In: Human Malformations and Related Anomalies., 2nd Eds, Chapter 22, 2006; 997-1020.

12. El-Gharbawy A.H., Peeden J.N., Lachman R.S., Graham J.M., Moore S.R., Rimoin D.L., Severe cleidocranial dysplasia and hypophosphatasia in a child with microdeletion of the C-terminal region of RUNX2. Am J Med Genet A. 2010 Jan; 152 A (1): 169-74. 